\title{
Metode Analitychal Hierarchy Process Dan Simple Multi Attribute Rating Technique Sebagai Penunjang Keputusan Pemilihan Supplier
}

\author{
Bayu Aji Setiyawan ${ }^{1)}$; Sri Siswanti ${ }^{2 *}$; Muhammad Hasbi ${ }^{3)}$ \\ 1) Program Studi Sistem Informasi, STMIK Sinar Nusantara Surakarta \\ $\left.{ }^{2 *}, 3\right)$ Program Studi Teknik Informatia, STMIK Sinar Nusantara Surakarta \\ ${ }^{1)}$ bayuajisetiyawan.96@gmail.com; ${ }^{2 *}$ syswanty@ sinus.ac.id $;{ }^{3)}$ mhasbi@ sinus.ac.id
}

\begin{abstract}
Process of choosing a supplier in Sukoharjo has not used the application program in making the decision but still use the manual way in writing. In addition, in conducting the selection of suppliers conducted by the HRD section is still subjective so that the results obtained in the selection of suppliers are less valid because in selecting HRD suppliers only choose based on price criteria, where If there is a supplier that offers the lowest price then the supplier will be chosen as a supplier in Sukoharjo. The purpose of the research is to build and implement a decision support system that is useful for the selection of suppliers in Sukoharjo using the method of Analyitychal Hierarchy Process (AHP) and Simple Multi Attribute Rating Technique (SMART). Where AHP method to calculate the weight of the criteria and SMART method to calculate the supplier's alignment. With testing black box system is already running according to the function and for the results of the validity test get the test value results in the category very good with a percentage of $80 \%$.
\end{abstract}

Keywords: Decision Support System, Supplier, AHP, SMART

\section{PENDAHULUAN}

Perusahaan industri untuk menghasilkan suatu produksi, peranan supplier sangat penting terutama untuk ketersedian bahan baku berkualitas yang tinggi yang diminati oleh konsumen dan menekankan keuntungan yang maksimal untuk perusahaan. Menilai supplier yang berkualitas, ada beberapa kriteria yang telah ditentukan perusahaan. Penilaian supplier yang berkualitas harus dilakukan untuk mengetahui supplier mana yang pantas untuk dijadikan langganan. Perusahaan tidak akan asal - asalan memilih supplier untuk perusahaan dan perusahaan akan mendapatkan untung yang maksimal.

Sistem yang berjalan di perusahaan saat ini adalah pemilihan supplier masih dilakukan secara manual dan dalam memilih supplier hanya memilih berdasarkan kriteria harga, dimana apabila ada supplier yang menawarkan harga paling murah maka supplier itu yang akan dipilih. Pengolahan data dan pengambilan keputusan masih manual yaitu dengan sistem tertulis dan bagian HRD sulit untuk menentukan supplier karena banyaknya supplier yang sama - sama memasang harga yang murah.

Berdasarkan permasalahan tersebut, maka pemanfaatan Analitychal Hierarchy Process(AHP) dan Simple Multi Attribute Rating Technique (SMART) digunakan untuk menunjang pemilihan supplier yang mana untuk menentukan bobot pada setiap kriteria menggunakan metode Analitychal Hierarchy Process dan hasil perangkingan supplier terbaik dengan metode Simple Multi Attribute Rating Technique.

Pemanfaatan AHP dan SMART untuk pemilihan supplier, dimana perhitungan bobot dengan AHP, penentuan Supplier berdasarkan rangking terbaik menggunakan SMART. (Rasiban et al., 2016), (Lestari \& Mahdiana, 2019). Hasil dari penelitian ini adalah metode AHP dan SMART dapat digunakan dalam menunjang keputusan pimpinan dalam menentukan supplier terbaik. Perbedaan dengan penelitian Rasiban, Saragih;, et al., (2016), yaitu pada kiriteria yang digunakan peneliti menggunakan kriteria harga, kualitas, pelayanan, pengiriman dan fleksibilitas, sedang Rasiban, Saragih;, et al., (2016) 
menggunakan kriteria qualified, standar produk, kompetisi, resiko dan harga. Perbedaan dengan penelitian Lestari \& Mahdiana, (2019) adalah penambahan kriteria fleksibilitas.

\section{TINJAUAN PUSTAKA}

Paper Angga Prayoga et al., (2016) perusahaan mengalami kendala dalam menentukan performasi terbaik dari supplier untuk penghematan biaya pengadaan barang dan memenuhi bahan baku penunjang yang dibutuhkan untuk memperlancar proses produksi. Tujuan penelitian adalah menentukan kriteria supplier yang baik, menentukan supplier terbaik dan menurunkan biaya pengadaan barang setelah supplier terbaik dipilih dengan menggunakan metode AHP. Variabel yang diteliti adalah Kualitas, Harga, Pengiriman, Pelayanan, Fleksibilitas dan garansi. Berdasarkan hasil kuesioner 1 menunjukkan bahwa kriteria yang baik dalam memilih supplier botol gallon adalah Kualitas, Harga, Pengiriman, Pelayanan, Fleksibilitas dan garansi. Pengolahan data pada Kuesioner 2 menggunakan metode AHP diketahui kriteria pengiriman menjadi prioritas utama yaitu dengan bobot 0,320 . Hasil penilaian dari kuesioner 3 yang sudah diolah menggunakan metode AHP menunjukkan PT. A sebagai prioritas pertama dengan bobot 0,401 . Ekspektasi penghematan biaya pengadaan botol gallon yang diperoleh PT. B sebesar 1,32 \% atau serata dengan Rp 18.809.800,- per minggu.

SMART dapat menunjang keputusan dalam menyelesaikan permasalahan multikriteria, setiap alternatif terdiri dari sejumlah kriteria yang memiliki nilai-nilai dan setiap kriteria memiliki bobot yang menggambarkan seberapa penting kriteria tersebut dengan kriteria lain. Hasil perhitungan dengan SMART digunakan dalam menentukan rekomendasi penerima dana bantuan yayasan (Andani, 2019).

Paper Sulistiyani et al., (2017) memiliki latar belakang masalah dari penelitian ini adalah perusahaan dalam memilih supplier bahan baku apel yang berdampak pada proses produksi. Tujuan penelitian dari paper (Sulistiyani et al., 2017) adalah mencari supplier yang sesuai dengan kriteria yang dibutuhkan oleh PT. Mannasatria Kusumajaya Perkasa. Perusahaan tersebut kedepannya akan menjadi supplier tetap yang akan memasok barang ke PT. Mannasatria Kusumajaya Perkasa. Variabel yang diteliti adalah Pengiriman, Kualitas, Finansial, Pelayanan dan Kondisi perusahaan. Metode yang dipakai untuk penyelesaian masalahnya adalah metode analytical hierarchy process (AHP). Hasil dari penelitian ini berdasarkan hasil perhitungan yang memiliki bobot tertinggi adalah kualitas $(0,454)$, diurutan kedua ada kondisi perusahaan dengan bobot 0,233 . selanjutnya urutan ketiga dan keempat secara berurutan ditempati oleh kriteria pengiriman dan pelayanan dengan bobot 0,174 dan 0,090 . sedangkan kriteria harga menempati urutan terakhir dengan bobot 0,049 . sementara itu, supplier 1 merupakan supplier yang tepat untuk dipilih karena mendapatkan bobot tertinggi, yaitu 0,375 .

\section{METODE PENELITIAN}

Wawancara dan observasi, cara ini untuk memperoleh data primer. Sedangkan studi pustaka menghasilkan data sekunder. Dalam penelitian ini menggunkakan langkah penelitian sebagai berikut :

(1) Melakukan Analisa Sistem, analisis yang dilakukan adalah :
a. Sistem yang sedang berjalan
b. Data supplier
c. Data nilai kriteria tiap supplier
d. Proses penentuan bobot tiap kriteria dengan metode AHP 
AHP merupakan metode yang sifatnya persepsional, artinya tingkat kepentingan dari suatu kriteria alternatif tergantung sudut pandang atau perspektif seseorang dalam menilainya. (Nofriansyah \& Defit, 2017)

Rumus yang digunakan dalam menghitung nilai konsistensi seperti rumus (1) dan menghitung rasio konsistensi seperti pada rumus (2).

- Menghitung nilai konsistensi :

$$
I=\frac{\lambda_{m a k s}-n}{n-1}
$$

Tabel 1. Indek Konsistensi

\begin{tabular}{|c|c|}
\hline Ukuran Matriks (n) & $\begin{array}{c}\text { Nilai IR (Indeks } \\
\text { Random) }\end{array}$ \\
\hline 1,2 & 0,00 \\
\hline 3 & 0,58 \\
\hline 4 & 0,90 \\
\hline 5 & 1,12 \\
\hline 6 & 1,24 \\
\hline 7 & 1,32 \\
\hline 8 & 1,41 \\
\hline 9 & 1,45 \\
\hline 10 & 1,49 \\
\hline 11 & 1,51 \\
\hline 12 & 1,48 \\
\hline 13 & 1,56 \\
\hline 14 & 1,57 \\
\hline 15 & 1,59 \\
\hline
\end{tabular}

- Menghitung rasio konsistensi :

$$
C R=\frac{C I}{I R}
$$

Jika $\mathrm{CR}=<0,1$ maka hasilnya konsisten.

Keterangan :

$\mathrm{N}$ = banyaknya kriteria

$\mathrm{CI}=$ Indeks Konsistensi (Consistency index)

$\mathrm{CR}=$ Rasio Konsistensi

IR = Indeks Rasio (nilai indeks rasio tergantung pada ukuran mariks)(Diana, 2018)

e. Proses perangkingan supplier dengan metode SMART

SMART merupakan teknik untuk menunjang pembutaan keputusan dalam memilih antara beberapa alternatif . Sesuai dengan tujuan yang dirumuskan, maka sebuah alternatif yang sesuai harus dipilih sebagai penunjang keputusan. (Nofriansyah \& Defit, 2017)

Nilai kriteria pada masing-masing kriteria dikonversi menjadi nilai kriteria bahan baku seperti pada rumus (3).

$$
U_{i}\left(a_{i}\right)=\frac{C_{o u t}-C_{\min }}{C_{\max }-C_{\min }}
$$

Keterangan :

$U_{i}\left(a_{i}\right) \quad$ : nilai utility kriteria ke i untuk alternatif ke i

$C_{\max } \quad$ : nilai kriteria maksimal 
$C_{\min } \quad$ : nilai kriteria minimal

$C_{\text {out }} \quad$ : nilai kriteria ke i

Nilai akhir masing-masing kriteria seperti pada rumus (4) di dapat dengan cara mengalikan nilai hasil normalisasi kriteria data baku dengan nilai normalisasi bobot kriteria, kemudian lakukan penjumlahan nilai dari perkalian tersebut.

$$
u\left(a_{i}\right)=\sum_{j}^{m}=1^{w_{j}} * u_{i}\left(a_{i}\right)
$$

Dimana :

$$
\begin{array}{ll}
u\left(a_{i}\right) & : \text { nilai total alternative } \\
w_{j} & : \text { hasil dari normalisasi bobot kriteria } \\
u_{i}\left(a_{i}\right) \quad: \text { hasil penentuan nilai utiliti }
\end{array}
$$

\section{f. Laporan pemilihan supplier}

Dalam tahap ini juga dilakukan analisis terhadap kebutuhan sistem baik hardware maupun software yang digunakan dalam pembuatan SPK pemilihan supplier.

(2) Desain Sistem

Menggambar sistem yang akan dibuat yaitu mengguankan Diagram Konteks dan Diagarm Alir Data.

(3) Implementasi Sistem

Implementasi sistem dengan menggunakan bahasa pemograman VB.Net dan database yang digunakan adalah Ms. Access.

(4) Pengujian Sistem

Pengujian validitas yaitu dengan membandingkan perhitungan sistem lama dengan perhitungan dari sistem aplikasi yang diusulkan.

\section{HASIL DAN PEMBAHASAN}

\subsection{Perhitungan AHP}

1. Membuat matriks perbandingan berpasangan. Dalam kasus ini kita memiliki 5 buah kriteria yakni kriteria $(K)=\{$ harga, kualitas, pelayanan, pengiriman dan fleksibilitas $\}$. Nilai pada matriks perbandingan berpasangan ini didasarkan pada penilaian pengambil keputusan. Berdasarkan asumsi masalah diatas bahwa :

- Harga sedikit lebih penting dari kualitas

- Harga sedikit lebih penting dari pelayanan

- Harga lebih penting dari pengiriman

- Harga mutlak lebih penting dari fleksiblitas

- Kualitas sama penting dengan pelayanan

- Kualitas sedikit lebih penting dari pengiriman

- Kualitas lebih penting dari fleksibilitas

- Pelayanan sedikit lebih penting dari pengiriman

- Pelayanan lebih penting dari fleksibilitas

- Pengiriman sedikit lebih penting dari fleksibilitas

Asumsi diatas masih berbentuk data kualitatif kita akan mengubah data kualitatif tersebut kedalam bentuk data kuantitatif dengan menggunakan Tabel 2. 
Tabel 2. Perbandingan Prioritas

\begin{tabular}{|c|l|}
\hline $\begin{array}{c}\text { Intesitas dari } \\
\text { kepentingan pada } \\
\text { skala absolute }\end{array}$ & \multicolumn{1}{|c|}{ Definisi } \\
\hline 1 & Kedua elemen yang sama pentingnya (Equal importance) \\
\hline 3 & $\begin{array}{l}\text { Elemen yang satu sedikit lebih penting dari pada elemen yang lainya } \\
\text { (Weak importance of one over another) }\end{array}$ \\
\hline 5 & $\begin{array}{l}\text { Elemen yang satu lebih penting daripada yang lainya (Essential or } \\
\text { strong importance) }\end{array}$ \\
\hline 7 & $\begin{array}{l}\text { Satu elemen jelas mutlak lebih penting daripada elemen lainya } \\
\text { (Demonstrated importance) }\end{array}$ \\
\hline 9 & $\begin{array}{l}\text { Satu elemen mutlak penting daripada elemen lainya (Extreme } \\
\text { importance) }\end{array}$ \\
\hline $2,4,6,8$ & $\begin{array}{l}\text { Nilai - nilai antara dua nilai pertimbangan - pertimbangan yang } \\
\text { berdekatan. Nilai ini diberikan bila ada dua kompromi diantara 2 } \\
\text { pilihan }\end{array}$ \\
\hline
\end{tabular}

Skala fundamental untuk perbandingan berpasangan seperti pada Tabel 3 :

Tabel 3 Perbandingan Prioritas Kriteria

\begin{tabular}{|c|c|c|c|c|c|}
\hline Kriteria & Harga & Kualitas & Pelayanan & Pengiriman & Fleksibilitas \\
\hline Harga & 1 & 3 & 3 & 5 & 7 \\
\hline Kualitas & 0,33 & 1 & 1 & 3 & 5 \\
\hline Pelayanan & 0,33 & 1 & 1 & 3 & 5 \\
\hline Pengiriman & 0,2 & 0,33 & 0,33 & 1 & 3 \\
\hline Fleksibilitas & 0,14 & 0,2 & 0,2 & 0,33 & 1 \\
\hline Total & 2,01 & 5,53 & 5,53 & 12,33 & 21 \\
\hline
\end{tabular}

2. Menghitung nilai eigen normalisasi. Untuk menghitung nilai vektor eigen normalisasi kita akan menggunakan Tabel 3 dengan cara mengalikan kolom dan baris sebagai berikut :

$$
a_{11}=(1 * 1)+(3 * 0,33)+(3 * 0,33)+(5 * 0,2)+(7 * 0,14)=4,96
$$

Nilai $a_{11}$ ini diperoleh dengan mengalikan baris 1 dengan kolom 1 , sedangkan $a_{12}$ diperoleh dengan mengalikan baris 1 dengan kolom 2, langkah yang sama untuk menentukan nilai matrik yang lain. Secara lengkap Nilai eigen normalisasi seperti pada Tabel 4.

Tabel 4 Eigen Normalisasi

\begin{tabular}{|c|c|c|c|c|c|}
\hline Kriteria & Harga & Kualitas & Pelayanan & Pengiriman & Fleksibilitas \\
\hline Harga & 4,96 & 2,95 & 1,79 & 1,04 & 0,52 \\
\hline Kualitas & 12,05 & 6,98 & 3,91 & 2,19 & 1,26 \\
\hline Pelayanan & 12,05 & 6,98 & 3,91 & 2,19 & 1,26 \\
\hline Pengiriman & 30,31 & 18,30 & 9,63 & 4,97 & 2,95 \\
\hline Fleksibilitas & 59,00 & 36,31 & 20,96 & 10,70 & 5,62 \\
\hline
\end{tabular}

Langkah selanjutnya menjumlahkan nilai pada baris, lalu menjumlahkan hasil penjumlahan secara keseluruhan dapat dilihat pada Tabel 5 .

Kolom $_{1}=4,96+12,05+12,05+30,31+59=118,37$

Kolom $_{2}=2,95+6,98+6,98+18,3+36,31=71,52$

Kolom $_{3}=1,79+3,91+3,91+9,63+20,96=40,20$ 


$$
\begin{aligned}
& \text { Kolom }_{4}=1,04+2,19+2,19+4,97+10,70=21,09 \\
& \text { Kolom }_{5}=0,52+1,26+1,26+2,95+5,62=11,61 \\
& \text { Total }_{\text {Kolom }}=118,37+71,52+40,20+21,09+11,61=262,79
\end{aligned}
$$

Tabel 5 Jumlah nilai baris

\begin{tabular}{|c|c|}
\hline Baris & Jumlah \\
\hline Kolom 1 & 118,37 \\
\hline Kolom 2 & 71,52 \\
\hline Baris 3 & 40,20 \\
\hline Baris 4 & 21,09 \\
\hline Baris 5 & 11,61 \\
\hline Total & $\mathbf{2 6 2 , 7 9}$ \\
\hline
\end{tabular}

3. Menghitung nilai eigen vektor. Nilai eigen vektor normalisasi dihasilkan dengan membagi nilai penjumlahan masing - masing baris dengan total keseluruhan dapat dilihat pada Tabel 6 .

$$
\begin{aligned}
& \text { Eigen Vektor }_{1}=118,37 / 262,79=0,45 \\
& \text { Eigen Vektor }_{2}=71,52 / 262,79=0,27 \\
& \text { Eigen Vektor }_{3}=40,20 / 262,79=0,15 \\
& \text { Eigen Vektor }{ }_{4}=21,09 / 262,79=0,08 \\
& \text { Eigen Vektor } \\
& 511,61 / 262,79=0,04
\end{aligned}
$$

Tabel 6 Eigen Vektor

\begin{tabular}{|c|c|}
\hline Kriteria & Eigen Vektor Normalisasi \\
\hline Harga & 0,45 \\
\hline Kualitas & 0,27 \\
\hline Pelayanan & 0,15 \\
\hline Pengiriman & 0,08 \\
\hline Fleksibilitas & 0,04 \\
\hline
\end{tabular}

4. Menentukan eigen maksimal. Nilai eigen maksimal $\lambda_{\text {maks }}$ diperoleh dengan mengalikan hasil penjumlahan setiap baris pada matriks perbandingan berpasangan dengan vektor eigen normalisasi.

$$
\lambda_{\text {maks }}=(2,01 * 0,45)+(5,53 * 0,27)+(5,53 * 0,15)+(12,33 * 0,08)+(21 * 0,04)=5,05
$$

5. Menghitung nilai indek konsistensi (CI). Berdasarkan pada persamaan 1 diperoleh:

$$
C I=\frac{5,05-5}{4}=0,013
$$

6. Menghitung rasio konsistensi (CR). Berdasarkan pada Tabel 2 diperoleh bahwa IR untuk matriks berukuran 5 x 5 adalah 1,12, sehingga berdasarkan pada persamaan 2 diperoleh :

$$
C R=\frac{0,013}{1,12}=0,012
$$

Karena CR $<0,1$ maka preferensi pembobotan adalah konsisten. 


\subsection{Perhitungan SMART}

1. Memberikan nilai kriteria untuk masing - masing supplier (dalam hal ini supplier merupakan alternatif yang akan dipilih).

Nilai kriteria pada Tabel 7 masih dalam bentuk kualitatif, sehingga kita perlu mengkonversi ke dalam data kuantitatif.

Tabel 7. Nilai tiap kriteria

\begin{tabular}{|c|c|c|}
\hline No & Kriteria & Nilai \\
\hline \multirow[t]{4}{*}{1} & Harga & \\
\hline & Murah & 5 \\
\hline & Standar & 3 \\
\hline & Mahal & 1 \\
\hline \multirow[t]{4}{*}{2} & Kualitas & \\
\hline & Sangat Berkualitas & 5 \\
\hline & Berkualitas & 3 \\
\hline & Kurang Berkualitas & 1 \\
\hline \multirow[t]{4}{*}{3} & Pelayanan & \\
\hline & Baik & 5 \\
\hline & Cukup & 3 \\
\hline & Kurang & 1 \\
\hline \multirow[t]{4}{*}{4} & Pengiriman & \\
\hline & Sangat Tepat & 5 \\
\hline & Tepat & 3 \\
\hline & Kurang Tepat & 1 \\
\hline \multirow[t]{4}{*}{5} & Fleksibilitas & \\
\hline & Baik & 5 \\
\hline & Cukup & 3 \\
\hline & Kurang & 1 \\
\hline
\end{tabular}

2. Menentukan nilai utiliti. Pada tahap ini kita harus memperhatikan jenis masing masing kriteria termasuk jenis 'lebih besar lebih baik' atau 'lebih kecil lebih baik'. Pada Tabel 8. Merupakan data awal semua kriteria termasuk dalam jenis kriteria 'lebih besar lebih baik', sehingga persamaan yang digunakan adalah persamaan (3) dapat dilihat pada Tabel 9.

Tabel 8. Data Awal

\begin{tabular}{|c|c|c|c|c|c|}
\hline $\begin{array}{c}\text { Nama } \\
\text { Supplier }\end{array}$ & Harga & Kualitas & Pelayanan & Pengiriman & Fleksibilitas \\
\hline Supplier 1 & Murah & Berkualitas & Cukup & Tepat & Baik \\
\hline Supplier 2 & Murah & Berkualitas & Baik & Sangat Tepat & Baik \\
\hline Supplier 3 & Standar & Berkualitas & Cukup & Sangat Tepat & Baik \\
\hline Supplier 4 & Murah & $\begin{array}{c}\text { Sangat } \\
\text { Berkualitas }\end{array}$ & Baik & Sangat Tepat & Baik \\
\hline Supplier 5 & Standar & $\begin{array}{c}\text { Kurang } \\
\text { Berkualitas }\end{array}$ & Baik & Tepat & Baik \\
\hline Supplier 6 & Murah & Berkualitas & Kurang & Tepat & Kurang \\
\hline Supplier 7 & Murah & $\begin{array}{c}\text { Sangat } \\
\text { Berkualitas }\end{array}$ & Cukup & Sangat Tepat & Cukup \\
\hline Supplier 8 & Standar & $\begin{array}{c}\text { Sangat } \\
\text { Berkualitas }\end{array}$ & Kurang & Kurang Tepat & Baik \\
\hline Supplier 9 & Mahal & $\begin{array}{c}\text { Berkualitas } \\
\text { Cukup }\end{array}$ & Tepat & Baik \\
\hline Supplier 10 & Mahal & Berkualitas & Baik & Tepat & Baik \\
\hline
\end{tabular}


Tabel 9. Nilai Utiliti

\begin{tabular}{|c|c|c|c|c|c|}
\hline Nama Supplier & Harga & Kualitas & Pelayanan & Pengiriman & Fleksibilitas \\
\hline Supplier 1 & 1 & 0,5 & 0,5 & 0,5 & 1 \\
\hline Supplier 2 & 1 & 0,5 & 1 & 1 & 1 \\
\hline Supplier 3 & 0,5 & 0,5 & 0,5 & 1 & 1 \\
\hline Supplier 4 & 1 & 1 & 1 & 1 & 1 \\
\hline Supplier 5 & 0,5 & 0 & 1 & 0,5 & 1 \\
\hline Supplier 6 & 1 & 0,5 & 0 & 0,5 & 0 \\
\hline Supplier 7 & 1 & 1 & 0,5 & 1 & 0,5 \\
\hline Supplier 8 & 0,5 & 1 & 0 & 0 & 1 \\
\hline Supplier 9 & 0 & 0,5 & 0,5 & 0,5 & 1 \\
\hline Supplier 10 & 0 & 0,5 & 1 & 0,5 & 1 \\
\hline
\end{tabular}

3. Menghitung nilai akhir. Tahap ini menggunakan persamaan 4 , untuk mempermudah kita gunakan data pada Tabel 9. Hasil dapat dilihat pada Tabel 10.

Tabel 10. Hasil Akhir

\begin{tabular}{|c|c|c|}
\hline Nama Supplier & Hasil Akhir & Rangking \\
\hline Supplier 1 & 0,76 & 4 \\
\hline Supplier 2 & 0,9 & 2 \\
\hline Supplier 3 & 0,56 & 6 \\
\hline Supplier 4 & 1 & 1 \\
\hline Supplier 5 & 0,52 & 7 \\
\hline Supplier 6 & 0,61 & 5 \\
\hline Supplier 7 & 0,88 & 3 \\
\hline Supplier 8 & 0,48 & 8 \\
\hline Supplier 9 & 0,29 & 10 \\
\hline Supplier 10 & 0,39 & 9 \\
\hline
\end{tabular}

\subsection{Desain Sistem}

Sistem yang dibuat seperti pada Gambar 1. Admin melakukan input data Admin, data perbandingan prioritas, data Supplier dan data nilai kriteria. Sistem melakukan proses perhitungan dan penyimpanan. Sistem mengirimkan hasil pemilihan supplier yang berbentuk laporan kepada Admin atau Asisten Direktur

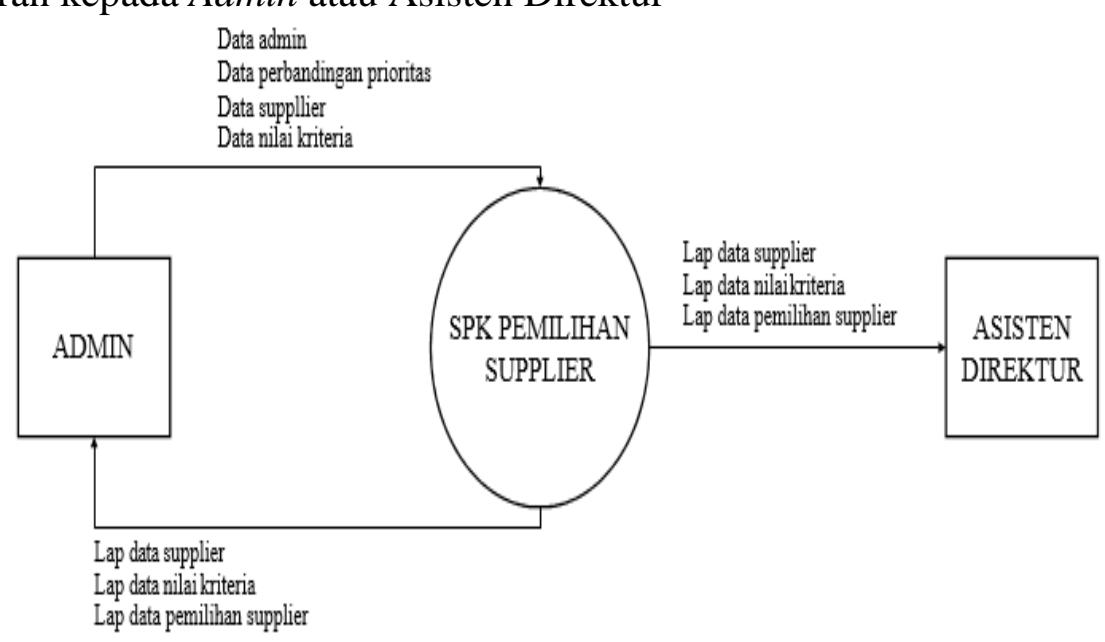

Gambar 1. Diagram Konteks 
Diagram Arus Data (DAD) Level 0 seperti pada Gambar 2. Pada DAD Level 0 terdapat 2 (dua) user yaitu Admin dan Asisten Direktur yang memiliki hak akses yang sama untuk mengelola data.

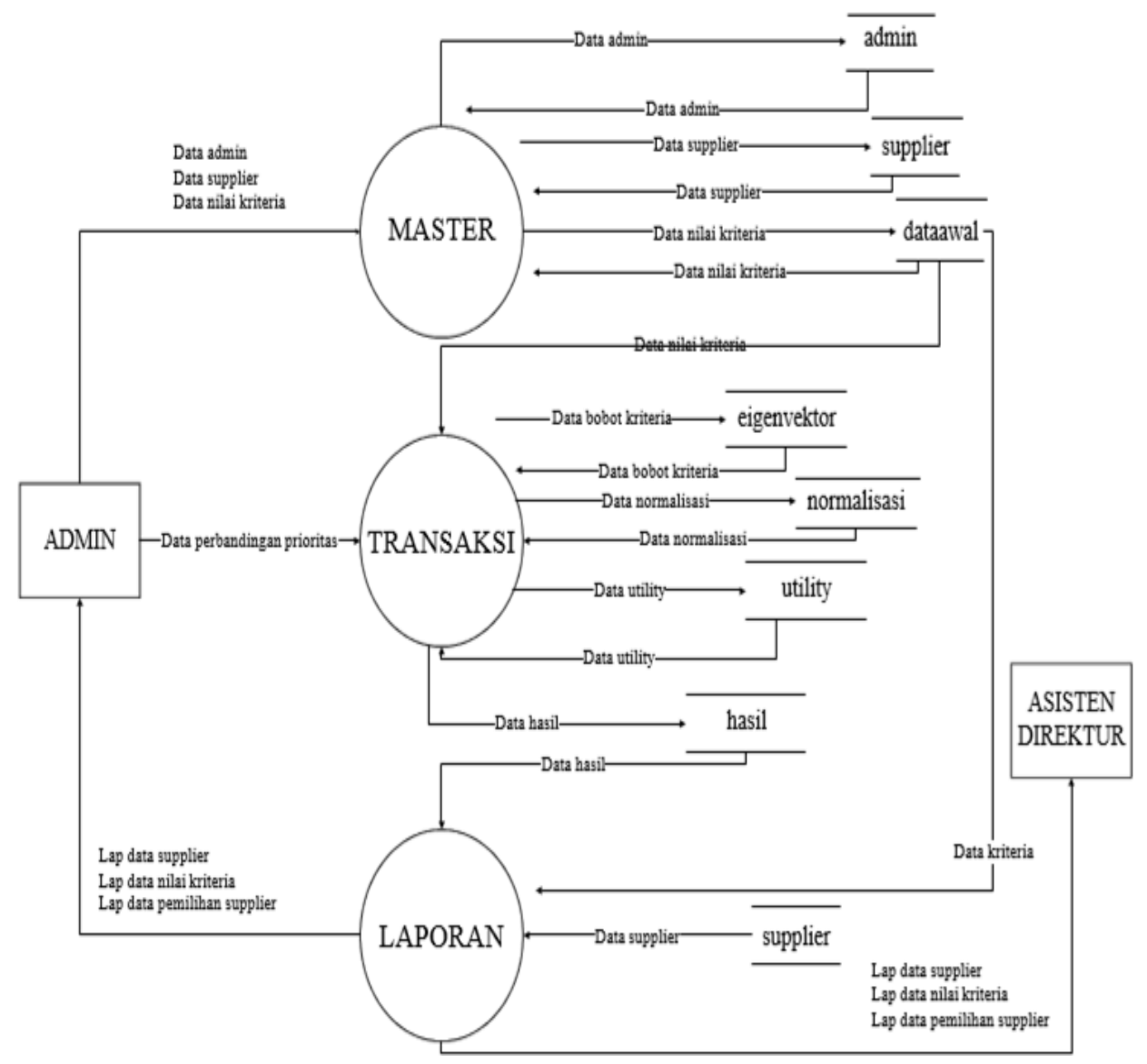

Gambar 2. Diagram Alir Data Level 0

\subsection{Aplikasi}

Pada Form Perbandingan Prioritas, admin melakukan input bobot intensitas kepentingan, kemudian sistem akan mengolah data intensitas kepentingan menjadi sebuah matriks. Hasil dari perbandingan prioritas akan diolah sistem menjadi normalisasi metode AHP, Eigen Vector, Eigen Maximum, Indeks Konsistensi dan Rasio Konsistensi.

Pada Form Input Kriteria Supplier, admin melakukan input bobot kriteria supplier dengan memasukan ID supplier maka sistem otomatis akan menampilkan data supplier yang dipilih, kemudian admin menilai supplier berdasarkan data yang ada.

Pada Form Input Data Supplier, admin melakukan input data supplier yang ada pada PT. Santosa Cipta Dian Prima Sukoharjo data supplier meliputi ID, Nama Supplier, Alamat, No. HP dan Barang yang dijual.

Laporan Hasil Pemilihan Supplier seperti pada Gambar 3, akan ditampilkan hasil pemilihan supplier pada PT. Santosa Cipta Dian Prima Sukoharjo dengan menggunakan perhitungan metode AHP dan SMART. 


\subsection{Pengujian}

\begin{tabular}{|c|c|c|c|}
\hline \multicolumn{4}{|c|}{ HASIL PEMILIHAN SUPPLIER TERBAIK } \\
\hline NO & NAMA SUPPLIER & HASIL & KETERANGAN \\
\hline 1 & Supplier 4 & 1 & Rangking 1 \\
\hline 2 & Supplier 2 & 0,9 & Rangking 2 \\
\hline 3 & Supplier 7 & 0,88 & Rangking 3 \\
\hline 4 & Supplier 1 & 0,76 & Rangking 4 \\
\hline 5 & Supplier 6 & 0,61 & Rangking 5 \\
\hline 6 & Supplier 3 & 0,56 & Rangking 6 \\
\hline 7 & Supplier 5 & 0,52 & Rangking 7 \\
\hline 8 & Supplier 8 & 0,48 & Rangking 8 \\
\hline 9 & Supplier 10 & 0,39 & Rangking 9 \\
\hline 10 & Supplier 9 & 0,29 & Rangking 10 \\
\hline
\end{tabular}

\section{Gambar 3. Laporan Hasil Perangkingan}

Pada pengujian Aplikasi menggunakan pengujian validitas yaitu denagn cara membandingkan perhitungan sistem yang saat ini denagn perhitungan secara komputerisasi. Hasil Pengujian seperti pada Tabel 11 dengan menggunakan 10 data sampel untuk mencari tingkat akurasi sistem.

Tabel 11. Pengujian Validitas

\begin{tabular}{|c|c|c|c|c|c|}
\hline No & Nama & $\begin{array}{c}\text { Rangking } \\
\text { (Sistem } \\
\text { Lama) }\end{array}$ & $\begin{array}{c}\text { Nilai Akhir (Aplikasi } \\
\text { Metode AHP dan } \\
\text { SMART) }\end{array}$ & $\begin{array}{c}\text { Rangking } \\
\text { (Sistem } \\
\text { Baru) }\end{array}$ & $\begin{array}{c}\text { Kesim } \\
\text { pulan }\end{array}$ \\
\hline 1 & Supplier 1 & 4 & 0,76 & 4 & {$[\mathrm{~T}]$} \\
\hline 2 & Supplier 2 & 2 & 0,9 & 2 & {$[\mathrm{~T}]$} \\
\hline 3 & Supplier 3 & 9 & 0,56 & 6 & {$[\mathrm{~F}]$} \\
\hline 4 & Supplier 4 & 3 & 1 & 1 & {$[\mathrm{~F}]$} \\
\hline 5 & Supplier 5 & 6 & 0,52 & 7 & {$[\mathrm{~F}]$} \\
\hline 6 & Supplier 6 & 8 & 0,61 & 5 & {$[\mathrm{~F}]$} \\
\hline 7 & Supplier 7 & 1 & 0,88 & 3 & {$[\mathrm{~F}]$} \\
\hline 8 & Supplier 8 & 10 & 0,48 & 8 & {$[\mathrm{~F}]$} \\
\hline 9 & Supplier 9 & 5 & 0,29 & 10 & {$[\mathrm{~F}]$} \\
\hline 10 & Supplier 10 & 7 & 0,39 & 9 & {$[\mathrm{~F}]$} \\
\hline
\end{tabular}

Keterangan

$\mathrm{T}=$ Benar. Jika data sampil sama dengan hasil perankingan.

$\mathrm{F}=$ Salah. Jika data sampel tidak sama denagn hasil perankingan

Penentuan kinerja SPK dengan menggunakan formula :

$$
\begin{aligned}
\text { Kinerja SPK } & =\frac{\text { Banyaknya hasil pengujian bernilai benar }}{\text { Banyaknya data sampel }} \times 100 \\
& =\frac{2}{10} \times 100 \% \\
& =20 \%
\end{aligned}
$$

Berdasarkan hasil analisa pengujian validitas pada Tabel 11 dengan menggunakan 10 sampel dan penentuan kinerja SPK terdapat tingkat kesamaan 20\% atau memiliki tingkat perbedaan $80 \%$. Hal tersebut disebabkan perbedaan saat perhitungan bobot dari tiap kriteria 
Antara proses manual dengan aplikasi, dimana perhitungan aplikasi tidak hanya dihitung dari nilai setiap kriteria tapi juga dikalikan dengan bobot kriteria.

\section{KESIMPULAN DAN SARAN}

\subsection{Kesimpulan}

(1) Sistem mengimplementasikan fitur - fitur seperti Input data supplier dan Input bobot tiap kriteria data kriteria tiap - tiap supplier menggunakan metode AHP serta output dari sistem ini adalah perangkingan dari tiap nilai kriteria supplier sehingga diperoleh alternatif keputusan penilaian supplier menggunakan metode SMART.

(2) Hasil pengujian validitas mendapatkan hasil presentase nilai persamaan 20\%. Dari hasil tersebut maka dapat disimpulkan bahwa sistem lama dan sistem baru memiliki tingkat perbedaan $80 \%$, karena sistem baru sudah dihitung dengan menggunakan metode - metode yang sudah diuji kelayakannya.

\subsection{Saran}

(1) Perlu adanya pengembangan SPK pemilihan Supplier dengan metode lain seperti : dengan TOPSIS, SAW atau metode WP yang dapat digunakan sebagai bahan perbandingan dan hasil alternatif yang dihasilkan lebih baik.

(2) Mengembangkan sistem ini secara online sehingga dapat melihat hasil dari sistem ini dimanapun berada.

\section{DAFTAR PUSTAKA}

Andani, S. R. (2019). Metode Simple Multi Attribute rating Technique ( SMART ) Dalam Menentukan Penerima Dana. Jurnal Sains Komputer \& Informatika (J-SAKTI), 3(September), 160-166.

Angga Prayoga, Y., Nursanti, E., \& Priyasmanu, T. (2016). Sistem Pendukung Keputusan Pemilihan Supplier Botol Galon Menggunakan Metode Analitychal Hierarchy Process (AHP). 2(2), 29-35.

Diana. (2018). Metode \& Aplikasi Sistem Pendukung Keputusan. CV BUDI UTAMA.

Lestari, A. B., \& Mahdiana, D. (2019). Penerapan Metode Analitycal Hierarchy Process Dan Simple Multi Attribute Rating Technique Untuk Pemilihan Supplier. Proceeding SINTAK 2019, 306-313.

Nofriansyah, D., \& Defit, S. (2017). Multi Criteria Decision Making (MCDM) Pada Sistem Pendukung Keputusan. Deep Publish.

Rasiban, Saragih;, H., \& Surapati, U. (2016). Pengembangan Sistem Pendukung Keputusan Pemilihan Pemasok Dengan Menggunakan Metode Analytical Hierarchy Process Dan Simple Multi Attribute Rating Technique. IX(02), 1-8.

Sulistiyani, E., Amir, M. I. H., R.K, Y., Nasrullah, \& Injarwanto, D. (2017). Implementasi Metode Analytical Hierarchy Process ( AHP) Sebagai Solusi Alternatif Dalam Pemilihan Supplier Bahan Baku Apel Di PT . Mannasatria Kusumajaya. Jechnology Science and Engineering Journal, 1(2), 87-101. 